\title{
自然资本价值核算研究综述
}

\author{
张彩平 ${ }^{1}$, 姜紫薇 ${ }^{1,2}$, 韩宝龙 ${ }^{2, *}$, 谭德明 ${ }^{1}$ \\ 1 南华大学经济管理与法学学院, 衡阳 421001 \\ 2 中国科学院生态环境研究中心,城市与区域生态国家重点实验室, 北京 100085
}

摘要: 目前国内外对自然资本价值核算的理论与方法尚未取得共识,无疑制约了自然资本核算在生态环境保护中积极作用的发 挥。基于此,本文分别从自然资本内涵及其价值核算理论基础、国内外自然资本存量与流量核算方法实证研究、自然资本货币 化价值核算的合理性等方面对已有文献进行梳理与分析, 发现目前自然资本核算研究主要集中在生态产品的功能量与价值量 核算而缺少生态资产货币价值量核算的研究; 当前采用的生态产品价值量核算的生态系统类型系数表、本地化生态过程模型、 能值当量替换三种方法在精度适用性、应用推广性和计算便捷性上各有优劣,尚待进一步的深人研究; 最后对自然资本货币核 算的一些争论进行了分析。通过上述研究和分析, 提出如下新认识: (1) 自然资本相关概念尚不统一, 已经形成的认识包括: 自 然资本具有一定的稀缺性和使用价值, 资本可分为存量资本 (又称生态资产) 和流量资本 (又称生态系统服务); (2) 自然资本核 算技术繁多,研究成果的横向比较性较差,需要通过标准化核算技术方法和建立生态环境资源数据库等措施,进一步提高核算 结果的准确性和可比性; (3) 相比于基于生态系统类型价值系数方法和基于非市场化货币的当量替代方法,基于本地化参数的 生态系统服务过程方法更能够反映本地生态环境特征,评估分析的准确度更高,生态管理抓手更多; (4) 尽管自然资本货币核 算理论和实践应用仍存在一些争论,但各国政府和各类组织都在推动自然资本核算工作,自然资本的探索性核算成果已在各国 生态补偿和生态损害修复等方面发挥积极作用。

关键词 : 自然资本; 生态资产;生态产品; 价值核算

\section{Review on natural capital valuation}

\author{
ZHANG Caiping ${ }^{1}$, JIANG Ziwei ${ }^{1,2}$, HAN Baolong ${ }^{2, *}$, TAN Deming ${ }^{1}$ \\ 1 School of Economics Management and Law, University of South China, Hengyang 421001, China \\ 2 State Key Laboratory of Urban and Regional Ecology, Research Center for Eco-Environmental Sciences. Chinese Academy of Sciences, Beijing \\ 100085, China
}

\begin{abstract}
At present, the theory and methodology of natural capital valuation have not reached a consensus domestically or internationally. This undoubtedly restricts the positive role of natural capital valuation played in the protection of the ecological environment. To address this issue, this paper analyzed the existing literature, including studies on the theoretical basis of value accounting, empirical accounting methods for stocks and flows, and the rationality of natural capital monetization. We found that natural capital valuation research tended to focus on product quantity, lacking exploration of the monetary value of ecological assets. Currently, three methods, including ecosystem type coefficient table, the localized ecological process model, and emergy-equivalent replacement for ecological product value, have been broadly adopted. They have their advantages and disadvantages in terms of precision applicability, application popularization, and calculation convenience, all of which need further study. In the end, this paper discussed some of the controversies surrounding the monetary accounting of natural capital. Through the above analysis, the paper puts forward the following conclusions:
\end{abstract}

基金项目:国家自然科学基金青年项目 (71804180); 国家社会科学基金一般项目(18BGL074)

收稿日期: 2020-06-24; 网络出版日期:2021-07-23

*通讯作者 Corresponding author.E-mail: blhan@ rcees.ac.cn 
(1) the concepts related to natural capital have not been unified. The natural capital has a certain scarcity and use value, and capital can be divided into stocks (also known as ecological assets) and flows (also known as ecosystem services). (2) The variety of natural capital valuation techniques leads to poor horizontal comparison of research results. It is necessary to improve the accuracy and comparability of accounting results by standardizing techniques and establishing ecologicalenvironmental resource databases. ( 3 ) Compared with the value coefficient method based on ecosystem type and the equivalent substitution method based on non-market valuation, the ecosystem service process method based on local parameters can better reflect the characteristics of local ecological and environmental conditions. The accuracy of evaluation and analysis is higher, and there are more ecological management channels. (4) Although there are still some debates about the theory and practical application of the monetary accounting of natural capital, governments and various organizations have promoted the work of natural capital valuation. The results of the exploratory accounting of natural capital have played a positive role in ecological compensation and restoration policies in various countries.

Key Words : natural capital; ecological assets ; ecosystem goods and services; valuation

2019 年 5 月,由 34 名专家组成的人类世工作组 (AWG, Anthropocene Work Group) 投票赞成以 20 世纪中 期作为人类世的起点。这意味着人类在地球上的生产、生活活动成为了主导的地质学因素, 并由此对整个地 球产生了广泛而深远的影响。快速的城镇化使人类对自然资源的占用不断增强,当资源环境迭代更新慢于城 市发展速度时,城市生态承载力将会超出极限, 出现生态退化、环境污染的后果 ${ }^{[1]}$ 。自然资本是能从中获得 有利于生计的资源流和服务流的自然资源存量 (如土地和水)和环境提供服务 (如水循环)。自然资本不仅包 括为人类所利用的资源, 如水资源、矿物、木材等,还包括森林、草原、沼泽等生态系统及生物多样性。长此以 往, 自然资源的稀缺性逐步形成并暴露, 自然资本取代人为资本成为人类社会发展的限制因素。只有人类重 新审视自然资源的稀缺性,科学评估自然资本价值,才能使人类对自然资源的占用符合人类社会规则, 实现生 态环境资源的良性循环 ${ }^{[2]}$ 。

在自然资本方面,我国不仅积极开展理论研究,更引领世界开展自然资本核算与管理的实践探索。习近 平总书记在多个重要场合提出 “绿水青山就是金山银山” ( 以下简称“两山论”) , “两山论”目前已经成为我国 社会进行生态文明建设的重要共识 ${ }^{[3]}$ 。2019 年 4 月,习总书记再一次强调“良好生态本身蕴含着无穷的经济 价值,能够源源不断创造综合效益,实现经济社会可持续发展”。2015 年, 中共中央国务院印发的《生态文明 体制改革总体方案》指出 “树立自然价值和自然资本的理念, 自然生态是有价值的, 保护自然就是增值自然价 值和自然资本的过程, 就是保护和发展生产力”。2017 年 10 月,中共中央、国务院《关于完善主体功能区战略 和制度的若干意见》明确在浙江、江西、贵州、青海等四省开展生态产品价值实现机制试点。世界银行认为自 然资本核算是维持经济增长所必需的。英国《金融时报》指出私营部门、政府、我们所有人都必须理解和解释 我们对自然资本的使用,并认识到其在维持经济增长方面的真正价值 ${ }^{[4]}$ 。

本文拟通过梳理相关文献,归纳自然资本核算领域的主要研究结论和进展, 从自然资本及其核算的内涵 与理论基础、国内外自然资本存量与流量核算实证研究特点、自然资本核算的争论三个方面加以梳理, 并据此 提出我国自然资本核算的一些思考和建议。

\section{1 自然资本及其核算的内涵与理论基础}

\section{1 自然资本的概念及内涵}

1992 年联合国环境与发展大会通过的《21 世纪议程》明确提出开展自然资本和生态系统评估研究,自然 资本核算研究自此兴起 ${ }^{[5-6]}$ 。Costanza ${ }^{[7]}$ 和 Daily ${ }^{[8]}$ 相继提出了各自的研究范式,并推动自然资本核算成为研 究热点。欧阳志云等 ${ }^{[9-11]}$ 在中国开展的一系列自然资本核算与应用则成为自然资本核算实践的典型代表。 近年来, 自然资本核算研究蓬勃发展、百花齐放, 以自然资本 (Natural capital) 为关键词的中英文文献从 
2000 年的 7524 篇增长为 2020 年的 54807 篇。

1992 年《21 世纪议程》明确提出的自然资本和生态系统评估可被视为研究的分水岭 ${ }^{[5-6]}$ 。1992 年以前, 自然资本概念处于萌芽发展阶段, 主要推动者为经济学家, 他们普遍将自然资本视为自然资源, 新古典经济学 家提出自然资本与自然资源区别不大的观点, 并强调在构造经济增长函数时可以使用自然资本的概念 ${ }^{[12]}$ 。 早在 1907 年, Roosevelt ${ }^{[13]}$ 就曾预见性地提出,一个国家的经济和社会想要发展得更好,需要民众把自然资源 视为资产的一部分。Vogt ${ }^{[14]}$ 在讨论国家债务时第一次提出自然资本的概念,并指出自然资本的耗竭会造成 国家偿债能力的降低。Pearce 和 Turner ${ }^{[5-15]}$ 在《自然资源与环境经济学》中明确提出自然资本, 并认为其与经 济增长函数中的人造资本相对应, 主要包括自然资源、生态潜力、环境质量以及满足人类物质和精神需求的生 态服务功能。

1992 年以后, 以 Costanza 和 Daily 为代表, 越来越多的生态学家加人研究阵营, 使自然资本的生态学内涵 更加清哳, 也使自然资本超越自然资源的范畴, 具有了更多 “隐性” 价值(生态系统调节服务与文化服务价 值)。Costanza ${ }^{[7]}$ 认为自然资本既包括诸如树木、矿产、生态系统、大气等有形的资本, 也包括各种无形的资 本, 为人类提供直接和间接的财富, 是全球总经济价值的一部分。Daily ${ }^{[8]}$ 对自然资本和生态系统服务的概 念、内容、发展历程以及价值核算的理论方法进行了系统说明, 认为自然资本是指生态系统产出的自然资源和 生态服务的总称, 可分为流量资本和存量资本两大部分。张志强 ${ }^{[16]}$ 认为自然资本包括人类所利用的水、土 壤、空气、鱼类等资源, 湿地、海洋、草原等整个生命系统, 以及提供给人类的多种服务功能。国内学者也对该 问题展开了研究, 如方恺 ${ }^{[17]}$ 将自然资本定义为人类利用的自然物质、能量及自然提供的生态服务总称。王美 红 ${ }^{[18]}$ 认为自然资本是在一定的经济、技术条件下可以被开发利用以提高人们生活福利水平和生存能力, 并同 时具有某种稀缺性、实物性资源的总称, 如能源、矿产、水资源等。

此外, 国内学者还使用生态资产这一概念。欧阳志云 ${ }^{[19]}$ 认为自然资本核算包括生态资产核算( 存量核 算) 和生态系统生产总值核算 (流量核算) 两部分。其中,生态资产是指能够生产和提供生态产品和服务的自 然资源。生态系统生产总值核算, 又称生态产品价值核算或生态系统服务价值核算, 是指在一定时间和空间 范围内, 生态系统为人类提供惠益的经济价值之和, 包括产品提供、调节服务、文化服务等方面 ${ }^{[20]}$ 。王健 民 $^{[21]}$ 从公共物品所有权和经济学视角指出生态资产是一切生态资源的价值形式, 是国家拥有的能以货币计 量的, 并能带来直接、间接或潜在利益的生态经济资源。这一定义在强调生态资产权属的同时, 也强调其潜在 的经济收益性。高吉喜 ${ }^{[13]}$ 则认为生态资产是在自然资源价值和生态服务价值两个概念的基础上发展起来 的, 是二者的结合与统一。

\section{2 自然资本及其价值核算的理论基础}

自然资本之所以能进行核算主要源于其对人类具有惠益性和稀缺性。生态系统对人类的惠益性主要体 现在产品生产 (如农产品提供、能源提供等)、调节服务 (如洪水调蓄、水源涵养等)、文化服务 (如旅游服务、教 育服务等), 这在学术界已经形成共识 ${ }^{[22]}$; 自然资本的稀缺性在于自然资源的形成速度远远小于人类对其的 消耗速度, 尤其是城市建设对生态空间的占用 ${ }^{[23]}$ 。

多数自然资本属于国家所有或集体所有 ${ }^{[24]}$, 当以行政单元为对象考察自然资本的稀缺性时, 其表现比以 个人为对象时更加明显。因此, 自然资本核算多以行政单元为对象。此外, 由于自然资本所有者和惠益享有 者在时空上的不一致,从而使得自然资本惠益具有外部性,也使自然资本核算成为客观要求。

由于自然资本对人类惠益性的存在，一些学者从福利经济学及可持续性角度理解自然资本 ${ }^{[25-26]}$ 。福利 经济学认为, 人是基本生存资源的平等享有者, 人类社会发展是以社会公益优先和长期福利优先为原则: 即各 类经济活动的本质是基本生存资源向生活福利的转化, 把生态环境看作人类可持续发展的福利条件。 Perring ${ }^{[27]}$ 和 Jansson ${ }^{[28]}$ 在研究自然资本与可持续性之间的关系后提出, 福利经济学是以追求人与自然和谐 一体前提下的可控、有效增长为目标。生态环境代价的支付可以视为现存福利的亏损, 将生态环境成本纳人 价格考量, 克服市场的外部性, 才能达到符合现代人的生存理念和对公平的追求 ${ }^{[29]}$ 。 
由于自然资本稀缺性的存在,一些学者用以马歇尔为代表的供求论和现代微观经济学家提出的边际效用 论来解释自然资源价值, 认为自然资源产品的价格包括资源开发利用的边际成本和边际机会成本 ${ }^{[30-31]}$ 。

由于自然资本所有者与其惠益享有者的不统一,一些学者认为多数自然资本属于公共物品或具有公共物 品的性质, 因此在价值衡量时还应针对不同的利益相关者进行判断。胡聑 ${ }^{[32]}$ 认为生态资产指特定时空条件 下生物与其环境之间的相互作用所产生的各种有形或无形价值的表现形态, 它常常具有一定的权属关系, 进 而产生资产所有权理论。而传统的产权属性是针对短期的有形资本,而自然资本具有长期性,且涵盖有形和 无形资本, 因此自然资本产权应充分考虑相应资本的属性和时效周期。此外,为了厘清自然资本所有者与受 益者之间的关系, 生态系统服务研究逐渐兴起, 通过构建合适的空间边界来实现对生态产品供需的科学

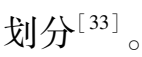

综上可知, 国内外学术界对自然资本的内涵并无明显争议和原则上的不同,主要的差异在于对自然资本 存量和流量的细分和认识。本文认为,细分自然资本的存量和流量更有利于相关研究和应用的逐步推进。以 生态资产表征自然资本存量凸显存量的经济价值, 而以生态产品表征生态系统服务则突出了流量的经济价值 特征,且“生态”相较“自然”更强调生态系统的生物物理过程, 突出“产品”的生产特点。因而, 总结当前自然 资本的主要内涵包括: (1) 自然资本对人类具有利用价值和稀缺性, (2) 自然资本包括自然资源 (存量资本, 也 称生态资产)和生态系统服务( 流量资本,也称生态产品)两个方面。

\section{2 自然资本核算实证研究进展}

\section{1 自然资本存量核算:生态资产核算}

自然资本存量, 又称为生态资产, 目前其核算仍以实物量为主, 涉及自然资源的数量和质量。如博文 静 ${ }^{[34]}$ 、董天 ${ }^{[11]}$ 、宋昌素等 ${ }^{[35]}$ 通过核算内蒙古兴安盟、鄂尔多斯市、青海省三地生态资产的面积和质量, 构建 了生态资产综合评价指标一一生态资产指数, 并开展了生态资产的评估。根据生态资产的质量和数量构建生 态资产的无量纲综合评价指标全面揭示三地生态资产的特征、数量和质量, 分析 2010 至 2015 年间各地生态 资产指数的动态变化, 并探讨评估生态保护的生态效益, 为其他地区的生态保护成效评估提供借鉴 ${ }^{[34-35]}$ 。白 杨 ${ }^{[36]}$ 针对云南省的生态资产质量进行了评估; 欧阳志云等以面向生态补偿的角度来分析云南峨山县和屏边 县、青海省、内蒙古兴安盟、黔东南州等地区生态资产状况。1993 年联合国统计司 (UNSD)、世界银行等组织 编制了《1993 国民核算手册: 综合环境和经济核算》(SEEA- 1993), 尝试将自然资源与环境纳人国民经济体 系，报告中“环境资产 (Environmental Asset)” 的概念和自然资本的定义十分类似: 提供环境 “功能”或服务的 自然存在的实体, 指所有的 (自然) 资产, 包括那些没有直接经济价值, 但带来间接使用价值、期权价值和遗赠 价值, 或不能转换为当前货币价值仅是存在价值的资产 ${ }^{[37]}$ 。同时, 英国、苏格兰等也在全国尺度对生态系统 和自然资源进行评估和保护自然资源和生态系统 ${ }^{[38-39]}$ 。

部分学者针对土地利用结构变化对生态资产价值的影响研究,进行了生态资产的货币价值量核算,谢高 地等 ${ }^{[40]}$ 进行了青藏高原及其草原生态系统的生态资产价值测算。王磊 ${ }^{[41]}$ 估算和分析土地利用变化给天津 市带来的生态资产价值变化, 并通过加人随机控制变量模型对天津市未来的生态资产价值量进行灰色预测。 Mathis 等 ${ }^{[42]}$ 先对英国以国家尺度进行自然资本核算, 接着在城市、地区、景区等更小尺度上使用自然资本核 算为组织决策提供信息, 并以此建立英国的城市自然资本账户。Ruijs 等 ${ }^{[43]}$ 通过对比分析私营部门和公共部 门自然资本核算方法、项目、目的的区别, 核算东非卢旺达 ${ }^{[43]}$ 、荷兰 ${ }^{[4]}$ 、印度尼西亚森林 ${ }^{[45]}$ 、伦敦区域 ${ }^{[42]}$ 等地 的自然资本价值,证明企业在自然资本核算和可持续发展目标中的作用。在此基础上,从合理调控土地利用 结构、系统核算生态资产价值、构筑生态文明保护屏障等角度提出相关的土地利用和生态资产保护的对策 建议。

目前,生态资产的核算方法仍存在众多争议,尤其是价值核算部分。由于生态资产概念尚未统一,因而对 生态资产价值化的研究从范围、方法到结果都存在较大差异, 而这种不确定性增加了评估和决策的应用难 
度 ${ }^{[46]}$ 。显然, 常规的经济社会领域的资产评估核算方法难以直接照搬到生态资产的核算评估中, 因为生态资 产评估面临许多技术、观念和制度等方面的问题 ${ }^{[47]}$ : 一是在概念上对生态资产还无准确、统一的界定; 二是由 于生态资产类型众多,甚至同一类别生态资产的核算技术方法在国内外一直存在诸多争议,导致目前尚无公 认的、统一的技术方法体系标准; 同时,生态资产核算评估需要资源、环境、生态等多年的大量数据作为支撑, 而我国生态环境资源数据基础相当薄弱, 存在环境基础数据缺失、环境数据质量和透明度不高等不足。再者, 自然资源提供产品与服务的价格历来是争论的焦点。

2.2 自然资本流量核算:生态产品核算

自然资本流量, 又可称为生态产品。根据 Daily ${ }^{[48]}$ 和欧阳志云 ${ }^{[22]}$ 的核算思路, 可以将生态产品核算分为 功能量核算和货币价值量核算两个阶段。归纳当前国内外学者在生态产品核算上采用的方法异同,可以梳理 为以下三种典型类型:

1) 基于生态系统类型价值系数方法 (landcover coefficient method), 以 Costanza ${ }^{[7]}$ 和谢高地 ${ }^{[47]}$ 为代表。 Costanza ${ }^{[7-49]}$ 最早基于生物物理过程及全球参数粗算了全球生态系统服务的功能量, 并用工程替代价值方法 核算出价值量,进而利用生态系统空间分布数据求取各生态系统类型上的单位面积价值量。谢高地 ${ }^{[40-50]}$ 将 这种方法引人中国, 并根据对原模型中的部分参数进行中国本地化, 由此获得了中国各类生态系统类型上的 单位面积价值量系数表。后续若干国内外学者使用生态系统类型空间分布数和生态系统类型价值系数就可 以计算出生态产品价值量 ${ }^{[41-51]}$ 。

该方法的优点是计算数据需求少, 仅需要知道各类生态系统的面积。缺点是计算结果精度不高, 一是生 态系统的质量未被考虑, 同类且同样面积的生态系统由于质量不同, 其发挥的生态系统服务能力和价值也是 显著不同的; 二是虽然一些学者在原方法的基础上, 通过增加质量权重系数, 对这个缺陷加以修正 ${ }^{[52]}$, 但其在 地理空间上的差异性不足, 如同类、同质且面积相同的湿地在不同地理气候区的生态系统服务功能量和价值量 的显著差异很难在该方法中得以体现 ${ }^{[10]}$ 。此外,由于该方法是直接对单位面积的各类生态系统赋值, 容易给人 造成该价值量是存量价值 (生态资产价值), 而不是流量价值 (生态产品价值) 的错觉。并且由于数据需求过于单 一, 导致基于这种方法计算出的结果用于指导生态管理实践时,管理抓手仅有生态系统类型和面积管控。

2) 基于本地化参数的生态系统服务生物物理过程方法 (bio-physical modeling method), 以 Daily ${ }^{[53]}$ 和欧阳 志云 ${ }^{[22]}$ 为代表。该方法坚持以本地化数据和参数为依托,利用各类生物物理模型对每个研究区开展针对性 的生态系统服务功能量评估, 并在功能量评估的基础上利用本地替代工程成本进行货币价值评估。为此, Daily ${ }^{[54]}$ 发起的 Natural Capital 项目还专门开发了免费使用的评估软件 InVEST (Integrated Valuation of Ecosystem Services and Tradeoffs)。利用该方法和软件, 欧阳志云等 ${ }^{[55-58]}$ 完成了中国生态系统服务评估以及若 干中国省市的生态系统服务价值评估工作。此外, 欧阳志云团队还结合中国生态环境监测数据特点, 开发了 包含若干生态系统服务类型评估的免费在线分析平台 IUEMS ( Intelligent Urban Ecosystem Management System)。该方法主要适用于具有一定生态学基础且掌握较丰富生态环境与地理数据的人员。Narita ${ }^{[25]}$ 对埃 塞俄比亚森林 2015 年的生态产品经济价值进行核算; Roy ${ }^{[44]}$ 对荷兰林堡 2010 年生态产品进行核算; 王敏 等 ${ }^{[59]}$ 评价了上海森林、灌丛、草地、湿地、农田、野生动物等提供的生态产品价值。Turner ${ }^{[60]}$ 通过使用相关集 成应用模型的价值评估方法对数据进行整合, 评估面向土地退化和恢复带来的生态系统服务价值变化, 分析 和评估所形成的土地管理方案, 以维持自然资本并最大化生态系统服务。Bagstad ${ }^{[61]}$ 通过对 17 种生态系统服 务评价工具的描述, 并根据 8 个评估标准对其价值进行评估, 提出在公共和私营部门决策中需要更具针对性 的本地化决策支持工具来支持更系统的生态系统服务评估。

该方法的缺点在于对数据需求较高, 无地理信息数据处理基础和非生态环境相关领域的人员较难操作, 不过 InVEST 和 IUEMS 项目组目前都在开展定期的免费培训, 以鼓励更多的人开展更为准确的生态系统服务 和价值评估。当然, 该方法的优点也十分明显:一是评估分析的准确度较高, 能够反映本地生态环境特征; 二 是丰富的数据需求意味着在进行生态管理时, 能够有更多的抓手用于分析和改进生态系统服务能力; 此外, 该 
方法体系在生态环境领域使用较多, 从而保障了该方法的科学合理性以及新生态系统服务模型更新的及 时性。

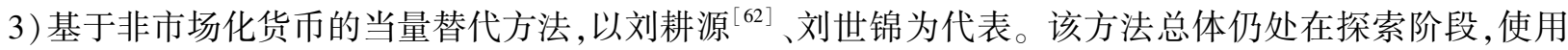
人数较少, 主要以部分国内学者为主, 但其差异特征明显。该方法以 Odum 的能值理论为基础, 认为从生物圈 能量运动角度出发, 所有物质和生产过程都能够通过太阳能能值转换率以太阳能当量 (太阳能能值焦耳) 表 征 ${ }^{[63]}$ 。因此,该方法在前述两方法的生物物理模型获取生态系统服务功能量的基础上,通过能值方法将不同 的生态系统服务功能量进行了单位统一,使其能够综合评价并进一步根据各国能值-货币换算表将能值转化 为人民币。刘耕源 ${ }^{[64]}$ 对京津冀城市群 2012 年森林生态系统服务价值进行核算。也有一些学者在能值当量 的基础上构建“生态元” 这一虚拟货币单位,用于表征生态系统服务的货币价值。在此基础上, Kenter ${ }^{[65]}$ 提出 了基于共享型多元化的文化价值评估方法。

相较前两种方法,该方法主要特点是用能值当量方法对生态服务不同单位的功能量进行单位统一,同时 回避以替代工程成本方法核算生态产品的货币价值。该方法的优点是脱离人类经济活动对生态产品进行价 值核算, 减少人类经济行为 (如定价) 对生态产品价值的影响。当然, 该方法的缺点也很明显:一是能值转换 率参数使用尺度大, 不能满足本地化精确计算的需要; 二是使用各国的能值-货币转换率进行货币价值核算, 该转换率的普适性和更新频率不够,无法满足管理的需要;三是太阳能能值或者“生态元” 虽然替代“传统货 币” 实现了多生态产品间的单位统一,但其不符合一般意义上的“价值” 内涵(即货币价值), 需要使用者有较 大的观念转变。

\section{表 1 典型自然资本核算方法比较}

Table 1 Comparison of typical natural capital accounting methods

\begin{tabular}{|c|c|c|c|}
\hline & $\begin{array}{l}\text { I. 基于生态系统类型价值系数 } \\
\text { 方法 } \\
\text { The value coefficient method based } \\
\text { on ecosystem type }{ }^{[40-66]}\end{array}$ & $\begin{array}{l}\text { II.基于本地化参数的生态系统 } \\
\text { 服务过程方法 } \\
\text { The equivalent substitution method } \\
\text { based on non-market } \\
\text { valuation }^{[9-67]}\end{array}$ & $\begin{array}{l}\text { III. 基于非市场化货币的当量替代 } \\
\text { 方法 } \\
\text { The ecosystem service process method } \\
\text { based on local parameters }{ }^{[62-64]}\end{array}$ \\
\hline $\begin{array}{l}\text { 尺度 (精度) } \\
\text { Scale( Accuracy) }\end{array}$ & 全国(一般) & 本地化(高) & 全国(一般) \\
\hline $\begin{array}{l}\text { 功能量计算 } \\
\text { Power calculation }\end{array}$ & $\begin{array}{l}\text { 简单 (生态系统类型价值系数 } \\
\text { 表) }\end{array}$ & $\begin{array}{l}\text { 复杂 (各类生态系统服务过程模 } \\
\text { 型) }\end{array}$ & 与 I 型或 II 型方法相同 \\
\hline $\begin{array}{l}\text { 价值量计算 } \\
\text { Value calculation }\end{array}$ & 简单(替代工程成本) & 简单(替代工程成本) & 简单(当量替代系数表) \\
\hline $\begin{array}{l}\text { 使用人群 } \\
\text { Use crowd }\end{array}$ & 广泛 & 生态环境领域 & 较少 \\
\hline $\begin{array}{l}\text { 管理实践 } \\
\text { Management practice }\end{array}$ & 抓手少 & 抓手多 & 较难理解 \\
\hline
\end{tabular}

\section{3 不同地区核算结果的比较}

针对文献所涉及的 24 个国内外地区、包括城市、省、州、城市群、国家等进行自然资本总量核算结果的横 向比较,由于核算指标、核算范围、核算方法、核算数据的不同,导致核算结果横向可比性较差。

\section{表 2 不同地区自然资本总量核算工作概况}

Table 2 Overview of accounting work in different regions

\begin{tabular}{lll}
\hline 核算地区 & 涉及生态产品 & 核算价值 \\
Accounting area & Ecosystem goods and services & Accounting value \\
\hline 青藏高原 & 森林、草地、农田、沼泽、湿地、湖泊、荒漠、冰川雪被、 & 9363.9 亿元( 2003 年) \\
Qingha-Tibet Plateau ${ }^{[40]}$ & 沙漠戈壁、荒漠 & 112.4 亿元( 2000 年) \\
长株潭地区 & 林地、草地、水体、耕地、建设用地 & 114.509 亿元 $(2010$ 年 $)$ \\
Changzhutan $^{[52]}$ &
\end{tabular}




\begin{tabular}{|c|c|c|}
\hline $\begin{array}{l}\text { 核算地区 } \\
\text { Accounting area }\end{array}$ & $\begin{array}{l}\text { 涉及生态产品 } \\
\text { Ecosystem goods and services }\end{array}$ & $\begin{array}{l}\text { 核算价值 } \\
\text { Accounting value }\end{array}$ \\
\hline $\begin{array}{l}\text { 抚仙湖流域 } \\
\text { Fuxian Lake Basin }{ }^{[68]}\end{array}$ & $\begin{array}{l}\text { 涵养水源、维持生物多样性、净化空气 土壤保持、调 } \\
\text { 节大气 }\end{array}$ & $\begin{array}{l}161.44 \text { 亿元 }(1992 \text { 年 }) \\
162.02 \text { 亿元 }(1996 \text { 年 }) \\
160.56 \text { 亿元 }(2001 \text { 年 }) \\
160.49 \text { 亿元 }(2006 \text { 年 }) \\
160.52 \text { 亿元 }(2010 \text { 年 }) \\
160.45 \text { 亿元 }(2014 \text { 年 })\end{array}$ \\
\hline 天津 Tianjin ${ }^{[41]}$ & 耕地、林地、建设用地、园地、水域和未利用地 & $\begin{array}{l}34.8988 \text { 亿元 }(2005 \text { 年) } \\
38.5935 \text { 亿元 }(2014 \text { 年 })\end{array}$ \\
\hline $\begin{array}{l}\text { 京津冀城市群 } \\
\text { Beijing-Tianjin-Hebei Urban } \\
\text { Agglomeration }{ }^{[64]}\end{array}$ & $\begin{array}{l}\text { 调节气候、固碳释氧、生物多样性、旅游休闲、文化 } \\
\text { 教育 }\end{array}$ & 987.7 亿元 $(2012$ 年) \\
\hline 上海市 Shanghai ${ }^{[59]}$ & $\begin{array}{l}\text { 农、林、水、畜牧产品、洪水调蓄、水源涵养、水资源、空 } \\
\text { 气净化、水质净化、固碳释氧、土壤保持、气候调节、生 } \\
\text { 态文化 }\end{array}$ & 5002.76 亿元 ( 2013 年) \\
\hline $\begin{array}{l}\text { 宁夏泾源县 } \\
\text { Jingyuan County, Ningxia }{ }^{[69]}\end{array}$ & $\begin{array}{l}\text { 气候调节 环境净化、气体调节、水源涵养 土壤保育、 } \\
\text { 生物多样性保护、休輴娱乐 }\end{array}$ & $\begin{array}{l}87.79 \text { 亿元 }(2000 \text { 年) } \\
98.09 \text { 亿元 }(2015 \text { 年 })\end{array}$ \\
\hline $\begin{array}{l}\text { 内蒙古兴安盟 } \\
\text { Xing' an League of Inner Mongolia }{ }^{[34]}\end{array}$ & 森林、灌丛、草地 湿地、湖泊、河流、沼泽 & $\begin{array}{l}\text { 指数 } 23.53(2000 \text { 年) } \\
24.04(2010 \text { 年) }\end{array}$ \\
\hline $\begin{array}{l}\text { 青海省 } \\
\text { Qinghai Province }{ }^{[35]}\end{array}$ & 森林、灌丛、草地、湿地 & $\begin{array}{l}\text { 指数 } 240.37(2000 \text { 年) } \\
278.22(2015 \text { 年) }\end{array}$ \\
\hline $\begin{array}{l}\text { 中国森林 } \\
\text { China Forest }\end{array}$ & $\begin{array}{l}\text { 林木产品、林副产品、气候调节、光合作用、固碳、涵养 } \\
\text { 水源、土壤保持、净化环境、养分循环、防风固沙、文化 } \\
\text { 多样性、休闲旅游、释放氧气、维持生物多样性 }\end{array}$ & 0.01518 亿元 ( 2000 年) \\
\hline $\begin{array}{l}\text { 中国草地 } \\
\text { Chinese grassland }{ }^{[71]}\end{array}$ & $\begin{array}{l}\text { 侵蚀控制、截留降水、气候调节、废弃物降解、营养物 } \\
\text { 质循环、空气质量调节、生境提供 }\end{array}$ & 0.009507 亿元 $(2000$ 年) \\
\hline $\begin{array}{l}\text { 鄱阳湖湿地 } \\
\text { Poyang Lake Wetland }{ }^{[72]}\end{array}$ & $\begin{array}{l}\text { 涵养水源、洪水调蓄、保护土壤、固定二氧化碳、释放 } \\
\text { 㧘气、污染物降解、生物栖息地 }\end{array}$ & 0.03663 亿元 ( 2002 年) \\
\hline $\begin{array}{l}\text { 鄂尔多斯市 } \\
\text { Ordos City }{ }^{[11]}\end{array}$ & $\begin{array}{l}\text { 水源涵养、土壤保持 防风固沙、大气净化 水质净化、 } \\
\text { 气候调节病虫害控制 }\end{array}$ & 指数 1998.19( 2015 年) \\
\hline 加拿大北方森林 Canadian boreal forest ${ }^{[73]}$ & $\begin{array}{l}\text { 气体调节、水源涵养 土壤保育、气候调节防风固沙、 } \\
\text { 生物多样性保护、休輴娱乐 }\end{array}$ & 37000 亿美元 (2010 年) \\
\hline $\begin{array}{l}\text { 巴西潘塔纳尔达赫克兰迪亚 } \\
\text { Pantanalda, Brazil }{ }^{[74]}\end{array}$ & $\begin{array}{l}\text { 防风固沙、大气净化 } \\
\text { 水源涵养、土壤保持 }\end{array}$ & 155 亿美元 (2012 年) \\
\hline $\begin{array}{l}\text { 荷兰林堡 } \\
\text { Limburg, Netherlands }[44]\end{array}$ & $\begin{array}{l}\text { 农作物生产、饲料生产、饮用水生产、空气质量调节、 } \\
\text { 碳封存、自然旅游和狩猎 }\end{array}$ & 1.12 亿欧元 $(2010$ 年) \\
\hline $\begin{array}{l}\text { 印度尼西亚加里曼丹中部 } \\
\text { Central Kalimantan, Indonesia }{ }^{[45]}\end{array}$ & $\begin{array}{l}\text { 四项供应服务 (木材 棕㭣油、藤条和水稻); 一项调节 } \\
\text { 服务 (碳封存) ; 两项文化服务 (自然休闲 和野生动物 } \\
\text { 栖息地) }\end{array}$ & 1.83 亿欧元 $(2010$ 年) \\
\hline 加利福尼亚州 California ${ }^{[75]}$ & $\begin{array}{l}\text { 大气调节、调蓄洪水 } \\
\text { 防风固沙、土壤保持 }\end{array}$ & 300 亿美元 (2009 年) \\
\hline $\begin{array}{l}\text { 伦敦巴尼特区 } \\
\text { Barnet, London } \\
\text { 东非卢旺达 }\end{array}$ & 娱乐和体育健康 & 19.4 亿英镑 (2017 年) \\
\hline Rwanda, East Africa ${ }^{[43]}$ & $\begin{array}{l}\text { 物质产品(茶叶,木材) } \\
\text { 土壤保持,水源涵养 }\end{array}$ & 12.1 亿美元 ( 2014 年) \\
\hline $\begin{array}{l}\text { 英国曼彻斯特 } \\
\text { Manchester, United Kingdom }{ }^{[42]}\end{array}$ & 体育健康 & 11 亿英镑 ( 2017 年) \\
\hline $\begin{array}{l}\text { 埃塞俄比亚森林 } \\
\text { Ethiopian Forest }{ }^{[25]}\end{array}$ & $\begin{array}{l}\text { 调节服务(固碳、水源涵养、土壤保持)；物质产品 (咖 } \\
\text { 啡) 文化服务 }\end{array}$ & 2.43 亿美元 ( 2013 年) \\
\hline 墨西哥 Mexico ${ }^{[43]}$ & $\begin{array}{l}\text { 气体调节、水源涵养 土壤保育、气候调节、生物多样 } \\
\text { 性保护 }\end{array}$ & 700 亿美元 (2013 年) \\
\hline
\end{tabular}


综合上述文献可知,不同地区的自然资本核算存在以下问题:

1) 即使在省级层面上,自然资本所核算的货币价值也存在着巨大的空间差异,这表明任何核算自然资本 货币价值的方法都需要考虑自然资源的空间异质性。

2) 地方尺度数据的缺失会导致价值核算在更精细尺度上存在较大的不准确性。

3) 自然资本价值量的多少与所选取的核算方法和核算范围有直接关联,从而导致各区域由于核算方法、 指标、范围的差异而使核算结果不具有可比性。

随着自然资本核算研究的不断深人,核算范围已经从早期的大尺度发展到近些年的小尺度,从生态环境 高脆弱性地区向经济发展的城市群研究转变, 这反映了近年来城镇化快速发展背景下探索城市生态文明的时 代特征。

\section{3 自然资本货币核算研究的一些争论}

虽然自然资本核算研究日益蓬勃,但仍有不少学者从伦理、市场形成可能性、定价方法的选择等角度争论 自然资本核算的合理性;这些争论对推动自然资本核算走向管理应用具有较大的启示性。

3.1 争论一:多数生态产品没有成熟的市场交易, 所以不能进行货币核算

Victor ${ }^{[4]}$ 认为, 就自然资本而言, 除了矿藏或作为私有财产的森林等生物资源之外,大多数形式的自然资 本或它们所提供的生态系统服务无法在市场上进行交易,所以不能进行定价。Ament ${ }^{[33]}$ 表示产品的价格往往 是由边际支付意愿决定, 由于生态产品市场没有充分竞争, 价格也就不能很好的反映消费者偏好的边际成本。 Quaas ${ }^{[76]}$ 认为市场价格在许多方面被用来指导公共和私营部门的决策, 由于真实的市场价格往往并不存在, 意味着需要使用模拟市场定价, 但模拟定价方法存在较大的争议性。

本文认为开展自然资本货币价值核算的目的有二：一是通过核算自然资本的货币价值,使更多公众能够 认识到自然资本的重要性,引导生态补偿和生态损害修复定价; 二是引导自然资本形成交易市场, 从而进人人 类社会生产体系的良性循环。目前的自然资本货币价值核算以流量货币价值(生态产品价值)核算为主,其 货币价值多是以实现同等生态产品的替代人工工程的价值表征, 虽然不能实现直接指导生态产品市场交易的 目的,但却达到了体现自然资本重要性和引导生态补偿与修复定价的目的。因此,本文认为, 虽然当前自然资 本货币价值核算工作仍处于探索阶段,但这种探索也具有很重要的现实意义,因而没必要苛求是否存在交易 市场。这或可成为今后学术界和生态资产管理者的重要研究方向。

3.2 争论二:由于自然资本货币价值被低估,可能造成社会不公平

Daly ${ }^{[77]}$ 认为自然资本的货币价值核算不能全面反映生态系统服务所贡献的全部价值。Narita ${ }^{[25]}$ 指出在 自然资本价值被低估的情况下,对其定价将使自然资本在私有化的过程中被过低估值, 从而恶化社会不公平 现象。

本文认为这种观点存在一定的片面性:一是无论是否开展生态系统服务价值核算, 自然资本的私有化和 市场交易一直都在进行, 其主要价格参考是资源价格。从这个角度来说, 对生态系统服务货币价值的衡量, 不 仅不会恶化社会不公平,反而能缓解部分生态产品作为公共产品分配的不公平性; 二是并不是所有的自然资 本最终都要私有化, 对公共自然资本进行定价的目的在于公共自然资本受损后的补偿和修复成本计算, 只有 不断加强和完善自然资本核算工作才能使公共自然资本受到有效保护。

3.3 争论三:当前各地开展的自然资本货币价值核算不具有可比性

Watson ${ }^{[19-38]}$ 认为由于统一标准化且具有科学性合理性的定价方法尚未确定,因而不同定价方法核算出 的自然资本价值可比性较差。不同定价方法的选择和不同生态产品的选择会在很大程度上影响自然及其服 务的货币价值估算。而且, 当前研究普遍缺乏对核算方法的比选, 没有明显的理由选择一种方法而不选择另 一种方法。此外, 由于缺乏真实生态产品交易市场, 对自然资本的货币化价值核算结果也难以验证。

本文认为当前各地开展的自然资本货币价值核算工作确实可比性较差, 主要原因是当前自然资本价值核 
算研究尚处在百家争鸣的探索阶段,未形成方法论上的普遍共识;而且,随着学术界对生态系统服务认识的不 断深化, 新的生态产品不断加人, 现阶段也难使自然资本核算指标固定下来。因此, 我们只有通过更多的测试 和经验,才能在最佳案例度量、评估技术、基线等方面取得一致 ${ }^{[78]}$ 。

但值得注意的是, 联合国统计署 SEEA 项目 ${ }^{[79]}$ 、英国等也已经开始展开相关探索, 以期为建立国家自然 资本账户提供更多证据; 中国政府也已在若干省、市开展生态产品价值实现和生态系统服务价值核算的试点 工作以及国家和地方标准的研究 ${ }^{[57-80]}$; World bank 也在积极组织相关方法和应用的讨论。自然资本联盟和 WAVES 成立的协作网络主张通过全面加速实践、应用和改进, 发展一种共同的方式来讨论自然资本, 并且从 消费者的角度看待自然资本提供公共和私人产品与服务的潜力以及整合和共享相关数据的能力 ${ }^{[25]}$ 。这些官 方行为将有效的推动自然资本核算的标准化。

表 3 现有研究的争论与启示

Table 3 Questions and Enlightenment of Existing Research

\begin{tabular}{|c|c|c|}
\hline $\begin{array}{l}\text { 现有研究存在的争论 } \\
\text { Controversy in existing research }\end{array}$ & $\begin{array}{l}\text { 争论的原因 } \\
\text { The reason for the dispute }\end{array}$ & $\begin{array}{l}\text { 个人观点 } \\
\text { Personal opinion }\end{array}$ \\
\hline $\begin{array}{l}\text { 模拟定价存在的争议 } \\
\text { Controversy over analog pricing }\end{array}$ & $\begin{array}{l}\text { 多数生态产品缺乏成熟的交易市场, 不能进 } \\
\text { 行货币核算 }\end{array}$ & $\begin{array}{l}\text { 体现自然资本重要性和引导生态补偿与修复 } \\
\text { 定价的目的 }\end{array}$ \\
\hline $\begin{array}{l}\text { 自然资本价值严重低估,进而恶化社会不公 } \\
\text { 平现象 } \\
\text { The value of natural capital is severely } \\
\text { underestimated }\end{array}$ & $\begin{array}{l}\text { 货币价值核算未能全面反映生态系统服务 } \\
\text { 贡献全部价值 }\end{array}$ & $\begin{array}{l}\text { 缓解了部分生态产品作为公共产品分配的不 } \\
\text { 公平性 }\end{array}$ \\
\hline $\begin{array}{l}\text { 自然资本货币价值核算不具有可比性 } \\
\text { The calculation of the monetary value of natural } \\
\text { capital is not comparable }\end{array}$ & $\begin{array}{l}\text { 统一、标准化具有科学性合理性的定价方法 } \\
\text { 尚未确定 }\end{array}$ & $\begin{array}{l}\text { 探索阶段,百家争鸣,未形成方法论上的普遍 } \\
\text { 共识; 现阶段也难使自然资本核算指标固定 } \\
\text { 下来 }\end{array}$ \\
\hline
\end{tabular}

\section{4 结论与建议}

\section{1 主要结论}

梳理近年来国内外关于自然资本核算的相关研究成果, 可得出如下主要结论:

(1) 自然资本核算主要包括生态资产存量核算和生态产品流量核算两类,其中存量与流量核算又分别可 以细分为实物量 (功能量) 核算和货币价值量核算两个阶段。围绕生态资产货币价值量核算的研究工作相对 较少,多数研究集中在生态产品的功能量与价值量核算。

(2) 当前学术界采用的生态产品价值量核算方法主要包括三类:生态系统类型系数表法、本地化生态过 程模型法、能值当量替换方法。三种方法在精度适用性、应用推广性和计算便捷性上各有优劣, 总体而言, 本 地化生态过程模型法的精度较高、在管理中的适用性较强,虽然计算较为繁琐,但已经有相关免费软件和培训 供大家使用。

(3) 当前自然资本核算中主要的问题:学术界研究都处于探索阶段,各类模型的验证性仍显不足、由于不 同学者在不同地区采用的模型和选择的指标不同,使不同研究间的可比性弱、当前的货币化定价方法均不是 基于实际市场交易, 尚不能直接用于指导自然资本交易市场形成。

4.2 对我国开展自然资本核算的启示

开展自然资本核算研究具有重要的理论价值、现实意义和社会影响, 主要启示如下:

(1) 理论价值方面, 自然资本核算工作对推动可持续发展、促进生态环境保护具有积极意义, 现有研究成 果可以支撑生态补偿、生态修复定价等实际应用。下一步应当在推动建立自然资本市场方面加大研究力度, 为绿水青山就是金山银山构建理论机制。 
(2) 现实意义方面,由于地理资源、气候条件等地区间的禀赋差异对自然资本价值的影响显著,应鼓励自 然资本核算过程中多使用本地化参数,这样既提高准确性,也对本地开展生态管理具有更强的指导意义。

(3) 社会影响方面,从社会福利经济学的视角分析可知,在推动自然资本核算应用过程中,要警惕并避免 自然资本私有化过程中的价值低估和资本流失,减少自然资本的社会分配不公平现象。

自然资本核算总体仍处在探索阶段,目前的理论研究和模型研究仍以生态学和环境学学者为主, 为了推 动自然资本核算的应用,并从后续应用中汲取优化意见,应鼓励生态经济、环境会计、公共管理、绿色金融等领 域的专家参与其中共同研究。

\section{参考文献 (References) :}

[1] 王杰. 中国城市生态文明建设的问题及出路. 郑州大学学报: 哲学社会科学版, 2015, 48(2) : 76-80.

[ 2 ] Daily G C, Kareiva P M, Polasky S, Ricketts T H, Tallis H. Mainstreaming natural capital into decisions: theory and practice of mapping ecosystem services//Kareiva P, Tallis H, Ricketts T H, Daily G C, Polasky S, eds. Natural Capital: Theory and Practice of Mapping Ecosystem Services. New York: Oxford University Press, 2011: 3-14.

[ 3 ] 王新庆. “绿水青山就是金山银山” 的基本形态生态资产及价值形式分析. 林业经济, 2019, 41(2) : 22-25.

[ 4 ] Victor P A. Cents and nonsense: a critical appraisal of the monetary valuation of nature. Ecosystem Services, 2020, 42: 101076.

[ 5] 刘洋, 王爱国. 自然资本核算研究的理论与方法综述. 会计之友, 2019, (3) : 26-31.

[ 6 ] Assessment M E. Ecosystems and Human Well-Being: Synthesis. Washington, DC: Island Press, 2005.

[ 7 ] Costanza R, d'Arge R, de Groot R, Farber S, Grasso M, Hannon B, Limburg K, Naeem S, O'Neill R V, Paruelo J, Raskin R G, Sutton P, van den Belt M. The value of the world's ecosystem services and natural capital. Nature, 1997, 387(6630) : 253-260.

[ 8 ] Daily G C. Nature's Services: Societal Dependence on Natural Ecosystems. Washington, DC: Island Press, 1997.

[ 9 ] 欧阳志云, 王效科, 苗鸿. 中国陆地生态系统服务功能及其生态经济价值的初步研究. 生态学报, 1999, 19(5): 607-613.

[10］江波，张路，欧阳志云. 青海湖湿地生态系统服务价值评估. 应用生态学报, 2015, 26(10): 3137-3144.

[11] 董天, 张路, 肖淡, 郑华, 黄斌斌, 欧阳志云. 鄂尔多斯市生态资产和生态系统生产总值评估. 生态学报, 2019, 39(9) : 3062-3074.

[12] 朱洪革, 蒋敏元. 国外自然资本研究综述. 外国经济与管理, 2006, 28(2): 1-6, 14-14.

[13] 高吉喜, 范小杉. 生态资产概念、特点与研究趋向. 环境科学研究, 2007, 20(5): 137-143.

[14] Vogt W. Road to Survival. New York: William Sloane, 1948.

[15] Turner R, Daily G. The ecosystem services framework and natural capital conservation. Environmental and Resource Economics, 2008, 39(1): 25-35.

[16] 张志强, 徐中民, 程国栋. 生态系统服务与自然资本价值评估. 生态学报, 2001(11): 1918-1926.

[17］方恺, Reinout H. 自然资本核算的生态足迹三维模型研究进展. 地理科学进展, 2012, 31(12)：1700-1707.

[18］王美红，孙根年，康国栋. 我国自然资本、人力资本与经济资本的空间错位分析. 科学学研究, 2009, 27 (1): 59-65.

[19］欧阳志云, 郑华, 谢高地, 杨武, 刘桂环, 石英华, 杨多贵. 生态资产、生态补偿及生态文明科技贡献核算理论与技术. 生态学报, 2016, $36(22): 7136-7139$.

[20］白玛卓嘎, 肖炏, 欧阳志云, 王莉雁. 基于生态系统生产总值核算的习水县生态保护成效评估. 生态学报, 2020, 40(2) : 499-509.

[21］王健民，王如松. 中国生态资产概论. 南京: 江苏科学技术出版社, 2001.

[22] 欧阳志云, 朱春全, 杨广斌, 徐卫华, 郑华, 张琰, 肖炏. 生态系统生产总值核算: 概念、核算方法与案例研究. 生态学报, 2013, 33 (21) : 6747-6761.

[23] 陈龙华. 关于自然资本的会计计量研究 [D]. 青岛: 中国海洋大学, 2008 .

[24] Engelbrecht H J. Natural capital, subjective well-being, and the new welfare economics of sustainability: some evidence from cross-country regressions. Ecological Economics, 2009, 69(2): 380-388.

[25] Narita D, Lemenih M, Shimoda Y, Ayana A N. Economic accounting of ethiopian forests: a natural capital approach. Forest Policy and Economics, 2018, 97: 189-200.

[26] Daly H E. Allocation, distribution, and scale: towards an economics that is efficient, just, and sustainable. Ecological Economics, 1992, 6( 3) : 185- 193 .

[27] Perrings C A. Biotic diversity, sustainable development, and natural capital/Jansson A, Hammer M, Folke C, Costanza R, eds. Investing in Natural Capital: the Ecological Economics Approach to Sustainability. Washington DC: Island Press, 1994: 128-149.

[28] Jansson A, Hammer M, Folke C, Costanza R. Investing in Natural Capital: the Ecological Economics Approach to Sustainability. Washington DC: 
Island Press, 1994.

[29] 李宪堂. 社会福利经济学的理念与构想——社会主义新经济学纲要. 聊城大学学报: 社会科学版, 2018, (6): 113-128.

[30］孔含笑, 沈镭, 钟帅, 曹植. 关于自然资源核算的研究进展与争议问题. 自然资源学报, 2016, 31(3): 363-376.

[31］梅林海, 邱晓伟. 从效用价值论探讨自然资源的价值. 生产力研究, 2012, (2) : 18-19, 104.

[32] 胡聑. 从生产资产到生态资产: 资产-资本完备性. 地球科学进展, 2004, 19(2)：289-295.

[33] Ament J. An ecological monetary theory. Ecological Economics, 2020, 171, 106421.

[34] 博文静, 肖焱, 王莉雁, 王效科, 欧阳志云. 生态资产核算及变化特征评估一一内蒙古兴安盟为例. 生态学报, 2019, 39(15)： 5425-5432.

[35］宋昌素, 肖炏, 博文静, 肖洋, 邹梓颖, 欧阳志云. 生态资产评价方法研究——以青海省为例. 生态学报, 2019, 39(1): 9-23.

[36] 白杨, 李晖, 王晓媛, Alatalo J M, 江波, 王敏, 刘文俊. 云南省生态资产与生态系统生产总值核算体系研究. 自然资源学报, 2017, 32 (7): 1100-1112.

[37] 周龙. 资源环境经济综合核算与绿色 GDP 的建立 [D ]. 中国地质大学(北京), 2011.

[38] Watson R, Albon S, Aspinall R, Austen M, Bardgett B, Bateman I, Berry P, Bird W, Bradbury R, Brown C, Bullock J, Burgess J, Church A, Christie C, Crute I, Davies L, Edwards-Jones G, Emmett B, Firbank L, Fitter A, Gibson A, Hails R, Haines-Young R, Heathwaite A L, Louise H, Hopkins J, Jenkins M, Jones L, Mace G, Malcolm S, Maltby E, Maskell L, Norris K, Ormerod S, Osborne J, Pretty J, Quine C, Russell S, Simpson L, Smith P, Tierney M, Turner K, Van der Wal R, Vira B, Walpole M, Watkinson A, Weighell A, Winn J, Winter M. UK National Ecosystem Assessment: Understanding Nature's Value to Society. Synthesis of Key Findings. Oxford: Information Press, 2011.

[39] Guerry A D, Polasky S, Lubchenco J, Chaplin-Kramer R, Daily G C, Griffin R, Ruckelshaus M, Bateman I J, Duraiappah A, Elmqvist T, Feldman M W, Folke C, Hoekstra J, Kareiva P M, Keeler B L, Li S Z, McKenzie E, Ouyang Z Y, Reyers B, Ricketts T H, Rockström J, Tallis H, Vira B. Natural capital and ecosystem services informing decisions: from promise to practice. Proceedings of the National Academy of Sciences of the United States of America, 2015, 112(24) : 7348-7355.

[40］谢高地, 鲁春霞, 冷允法, 郑度, 李双成. 青藏高原生态资产的价值评估. 自然资源学报, 2003, 18(2)：189-196.

[41］王否, 薛雅君, 张宇. 基于土地利用变化的天津市生态资产价值评估及灰色预测. 资源开发与市场, 2017, 33(7): 796-801.

[42] Mathis, Wackernagel, and, et al. National natural capital accounting with the ecological footprint concept. Ecological Economics, 1999, 28(7): 108- 117 .

[43] Ruijs A, Vardon M, Bass S, Ahlroth S. Natural capital accounting for better policy. Ambio, 2019, 48(7) : 714-725.

[44] Remme R P, Edens B, Schröter M, Hein L. Monetary accounting of ecosystem services: a test case for Limburg province, the Netherlands. Ecological Economics, 2015, 112: 116-128.

[45] Sumarga E, Hein L, Edens B, Suwarno A. Mapping monetary values of ecosystem services in support of developing ecosystem accounts. Ecosystem Services, 2015, 12: 71-83

[46] 刘炎序, 傅伯杰, 赵文武, 王帅. 生态资产核算与生态系统服务评估: 概念交汇与重点方向. 生态学报, 2018, 38(23)：8267-8276.

[47］谢高地, 鲁春霞, 成升鬼. 全球生态系统服务价值评估研究进展. 资源科学, 2001，23(6)：5-9.

[48］Daily G C, 欧阳志云, 郑华, 李树茁, 王玉宽, Feldman M, Kareiva P, Polasky S, Ruckelshaus M. 保障自然资本与人类福祉: 中国的创新 与影响. 生态学报, 2013, 33(3) : 669-676.

[49] Costanza R, Daly H E. Natural capital and sustainable development. Conservation Biology, 1992, 6(1) : 37-46.

[50］谢高地, 张钇锂, 鲁春霞, 郑度, 成升鬼. 中国自然草地生态系统服务价值. 自然资源学报, 2001, 16(1): 47-53.

[51］谢高地, 张彩霞, 张雷明, 陈文辉, 李士美. 基于单位面积价值当量因子的生态系统服务价值化方法改进. 自然资源学报, 2015, 30(8)： 1243-1254.

［52］李毅, 杨仁斌, 毕军平, 周妮笛, 易敏, 胡文敏. 长株潭地区生态资产变化格局分析. 经济地理, 2015, 35(2) : 184-188, 208-208.

[53] 刘颂, 戴常文. 自然资本的流变及其对生态系统服务价值化的启示. 生态学报, 2021, (3): 1-10 [2021-02-01]. http://kns.cnki.net/ kcms/detail/11.2031.q.20201211.2049.010.html.

[54 Daily G C, Polasky S, Goldstein J, Kareiva P M, Mooney H A, Pejchar L, Ricketts T H, Salzman J, Shallenberger R. Ecosystem services in decision making: time to deliver. Frontiers in Ecology and the Environment, 2009, 7(1): 21-28.

[55]游旭, 何东进, 肖炏, 博文静, 宋昌素, 欧阳志云. 县域生态资产核算研究——云南省屏边县为例. 生态学报, 2020,40(15)： 5220-5229.

[56] 杨渺, 肖炎, 欧阳志云, 叶宏, 艾蕾, 邓惁涛. 生态系统流动性资产核算方法一一以四川省各县域水土保持功能为例. 环境保护科学, 2019, 45(1): 44-50

[57] 王莉雁, 肖焱, 欧阳志云, 韦勤, 博文静, 张健, 任苓. 国家级重点生态功能区县生态系统生产总值核算研究一一以阿尔山市为例. 中国 人口・资源与环境, $2017,27(3):$ 146-154. 
[58] 孔令桥, 郑华, 欧阳志云. 基于生态系统服务视角的山水林田湖草生态保护与修复一一洞庭湖流域为例. 生态学报, 2019, 39(23): 8903-8910.

[59］王敏, 江波, 白杨, Alatalo J M, 王晓媛, 黄沈发, 谭娟. 上海市生态资产核算体系研究. 环境污染与防治, 2018, 40(4)：484-490.

[60] Turner K G, Anderson S, Gonzales-Chang M, Costanza R, Courville S, Dalgaard T, Dominati E, Kubiszewski I, Ogilvy S, Porfirio L, Ratna N, Sandhu H, Sutton P C, Svenning J C, Turner G M, Varennes Y D, Voinov A, Wratten S. A review of methods, data, and models to assess changes in the value of ecosystem services from land degradation and restoration. Ecological Modelling, 2016, 319: 190-207.

[61 ] Bagstad K J, Semmens D J, Waage S, Winthrop R. A comparative assessment of decision-support tools for ecosystem services quantification and valuation. Ecosystem Services, 2013, 5: 27-39.

[62］刘耕源. 生态系统服务功能非货币量核算研究. 生态学报, 2018, 38(4) : 1487- 1499.

[63] Odum H T. Emergy accounting//Bartelmus P. Unveiling Wealth: On Money, Quality of Life and Sustainability. Dordrecht: Springer, 2002 : 135- 146.

[64] 杨青, 刘耕源. 森林生态系统服务价值非货币量核算: 以京津冀城市群为例. 应用生态学报, 2018, 29(11): 3747-3759.

[65] Kenter J O. Editorial: shared, plural and cultural values. Ecosystem Services, 2016, 21: 175- 183.

［66］谢高地. 生态资产评价: 存量、质量与价值. 环境保护, 2017, 45(11) : 18-22.

[67］欧阳志云, 郑华. 生态系统服务的生态学机制研究进展. 生态学报, 2009, 29(11)：6183-6188.

[68］杨艳林, 王金亮, 李石华, 杨超. 基于生态绿当量模式的生态资产核算研究一一抚仙湖流域为例. 资源开发与市场, 2017, 33(5)： 513-517.

[69] 王红岩, 高志海, 李增元, 王琫瑜, 白黎娜, 王志波, 吴俊君. 县级生态资产价值评估一一以河北丰宁县为例. 生态学报, 2012, 32(22): 7156-7168.

[70］赵同谦，欧阳志云，郑华，王效科，苗鸿. 中国森林生态系统服务功能及其价值评价. 自然资源学报，2004，19(4)：480-491.

[71］赵同谦, 欧阳志云, 贾良清, 郑华. 中国草地生态系统服务功能间接价值评价. 生态学报, 2004, 24(6): 1101-1110.

[72] 崔丽娟. 鄱阳湖湿地生态系统服务功能价值评估研究. 生态学杂志, 2004, 23(4) : 47-51.

[73] De Groot R, Brander L, van der Ploeg S, Costanza R, Bernard F, Braat L, Christie M, Crossman N, Ghermandi A, Hein L, Hussain S, Kumar P, McVittie A, Portela R, Rodriguez L C, ten Brink P, van Beukering P. Global estimates of the value of ecosystems and their services in monetary units. Ecosystem Services, 2012, 1(1): 50-61.

[74] Klain S C, Satterfield T A, Chan K M A. What matters and why? Ecosystem services and their bundled qualities. Ecological Economics, 2014, $107: 310-320$.

[75] Boithias L, Terrado M, Corominas L, Ziv G, Kumar V, Marqués M, Schuhmacher M, Acuña V. Analysis of the uncertainty in the monetary valuation of ecosystem services-a case study at the river basin scale. Science of the Total Environment, 2016, 543: 683-690.

[76] Quaas M, Baumgärtner S, De Lara M. Insurance value of natural capital. Ecological Economics, 2019, 165: 106388.

[77] Daly H. A note in defense of the concept of natural capital. Ecosystem Services, 2020, 41: 101051.

[78] Özdemiroğlu E. Natural capital-a practitioner's overview of concepts and applications. Journal of Environmental Economics and Policy, 2019, 8 (4) : 343-352.

[79] 张颖. 生态资产核算和负债表编制的统计规范探究——基于 SEEA 的视角. 中国地质大学学报: 社会科学版, 2018, 18(2): 92-101.

［80］赵越, 王海舰, 苏釒. 森林生态资产资本化运营研究综述与展望. 世界林业研究, 2019, 32(4) : 1-5. 